\title{
Biyolojik Temelli Uygulamaların İnfertil Kadınlar Üzerindeki Etkisine Güncel Bir Bakış
}

\section{A Current Overview on the Effect of Biological Applications on Infertile Women}

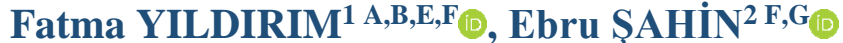 \\ ${ }^{1}$ Hitit Üniversitesi, Sağlık Bilimleri Fakültesi, Doğum ve Kadın Hastalıkları Hemşireliği Ana Bilim Dalı, Çorum, Türkiye \\ ${ }^{2}$ Ordu Üniversitesi, Sağlık Bilimleri Fakültesi, Doğum ve Kadın Hastalıkları Hemşireliği Ana Bilim Dalı, Ordu, \\ Türkiye
}

ÖZ

\begin{abstract}
İnfertilite, 12 ay veya daha fazla sürede, düzenli korunmasız cinsel ilişkide bulunulmasına rağmen gebeliğin oluşmaması olarak tanımlanan bir üreme sistemi hastalığıdır. Çiftlerin bir kısmı anlaşmaya dayalı infertilite tedavisi öncesinde, tedavi esnasında ya da olumsuz sonuçlanan tedaviler sonrasında tamamlayıcı ve alternatif tıp uygulamalarına yönlenmektedir. Tamamlayıcı alternatip tıp yöntemleri, çeşitli ölçülebilir ve ölçülemeyen mekanizmalar yoluyla hareket eden çok çeşitli uygulamaları kapsamaktadır. Bu yöntemler arasında en sık kullanılanlardan birisi de biyolojik temelli uygulamalardır. Kadın infertilitesinde başvurulan biyolojik temelli uygulamaların tıbbi tedaviye ek olarak kullanımının faydalarına yönelik farklı sonuçlar ortaya konulduğu tespit edilmiştir. Bu derlemede biyolojik temelli uygulamaların infertil kadınlara etkisi ele alınmıştır.
\end{abstract}

Anahtar Kelimeler: İnfertilite, Tamamlayıcı-alternatif tıp, Kanıta dayalı hemşirelik.

\section{ABSTRACT}

Infertility is a disease of the reproductive system defined as the failure of pregnancy despite regular unprotected sexual intercourse for 12 months or more. Some of the couples are directed to complementary and alternative medicine practices before, during treatment or after treatments that result in negative results. Complementary and alternative medicine methods cover a wide range of applications acting through a variety of measurable and unmeasurable mechanisms. One of the most frequently used methods among these methods is biological-based applications. It has been determined that different results have been revealed regarding the benefits of using bio-based applications in female infertility in addition to medical treatment. In this review, the effect of biologically based practices on infertile women is discussed.

Key Words: Infertility, Complementary-alternative medicine, Evidence-based nursing.

\section{GíRiș}

Dünya Sağlık Örgütü’nün (WHO) tanımına göre infertilite, 12 ay veya daha fazla sürede, düzenli korunmasız cinsel ilişkide bulunulmasına rağmen gebeliğin oluşmaması olarak tanımlanan bir üreme sistemi hastalığıdır (1). Çiftlerin bir kısmı anlaşmaya dayalı infertilite tedavisi öncesinde, tedavi esnasında ya da olumsuz sonuçlanan tedaviler sonrasında tamamlayıcı ve alternatif tıp uygulamalarına (TAT) başvurmaktadır. İnfertilite tedavisi alan kadınların \%29.9-91.0’1 TAT tedavilerine yöneldiği bildirilmektedir (2,3).

Dünya Sağlık Örgütü'ne göre, dünya nüfusunun dörtte üçünden fazlası sağlık hizmetleri için TAT’a güvenmektedir. Edirne ve arkadaşlarının aktardığına göre Cochrane İşbirliği'nin 
TAT tanımı; belirli bir toplumda veya kültürde politik olarak baskın olan sağlık sistemlerine özgü olanlar dışındaki tüm sağlık sistemlerini, yöntemleri ve uygulamaları ve bunlara eşlik eden teorileri ve inançları kapsayan geniş bir iyileştirme kaynakları alanı olarak aktarılmaktadır (3).

Hem infertilite hastaları hem de doktorlar tarafindan TAT kullanımı son otuz yılda belirgin bir şekilde artmıştır. Hastalar sıklıkla bu tedavileri biyomedikal tedaviye ek olarak ya da bunun yerine kullanmaktadır. TAT müdahaleleri, çeşitli ölçülebilir ve ölçülemeyen mekanizmalar yoluyla hareket eden çok çeşitli müdahaleleri kapsamaktadır. $\mathrm{Bu}$ yöntemler arasında en sık kullanılanlardan birisi de biyolojik temelli uygulamalardır (4). Uygulamalar içerisinde doğal maddelerin var olduğu vitamin, mineral ve yiyecekler üzerine dayanmaktadır (5).

Biyolojik temelli uygulamaların kullanımına yönlendiren değişkenler toplumlar arası farklılık gösterebilmektedir. Bu farklılıklar; konvansiyonel tedavi sonuçlarından memnun olmama, bu uygulamaların zararsız olduğuna inanma, doğal ya da konvansiyonel tedavi yöntemlerinden daha etkili olduğunu düşünme, çiftlerin kendi tedavilerinde daha etkin rol almak istemeleri şeklinde sıralanmaktadır (6).

Tamamlayıcı ve alternatif tıp bakım uygulamalarının infertilite tedavisinde gün geçtikçe daha çok yaygınlaştığı görülmektedir. Bu derlemenin amacı, biyolojik temelli uygulamaların infertil kadınlara etkisini ortaya koymaktır. İnfertilite için kullanılan bazı biyolojik temelli uygulamalar şöyledir:

\section{Fitoöstrojenler}

Fitoöstrojenler yapay ya da doğal östrojenik bileşiklere benzeyen kimyasal yapıları olan bitkiler tarafından üretilen nonsteroid bileşiklerdir (7). Yapılan vaka çalışmalarında, bazı fitoöstrojenlerin çalışma prensiplerinin açığa çıkarılması için çalışılmıştır (8). Fitoöstrojenler, östrojen gibi östrojen reseptörü alfa ve betaya bağlanma kodlanması ile büyük oranda benzerlik göstermektedir $(8,9)$. Fitoöstrojenler ligand ile reseptörlere bağlandıktan sonra sitoplazmadan çekirdeğe geçerek spesifik genlerin ekspresyonu gerçekleşmektedir. Ayrıca, fitoöströjenler steroide benzer yapı gösterdikleri için, hücre yüzeyinde bulunan reseptörlere de bağlanabilme yeteneği gösterirler (10). Bu özellikleri sebebi ile fitoöstrojenlerin, östrojenler ile regüle edilen cinsiyet hormonu bağlayıcı globülin (SHBG) sentezi ve testosteronun aromatizasyonunu baskılayan tüm süreçlerde etken olduğu belirtilmektedir (7). Karayılan otunun, fitoöstrojen içeren 1-12 günlük sikluslarla $120 \mathrm{mg}$ verilen kadınlarda, LH düzeyinde artış gösterdiği bildirilmiştir. Fitoöstrojenlerin; östrojen düzeyi, nedeni belli olmayan infertilite, endometrial kalınlık ve gebelik oranlarında etkili olduğu belirtilmektedir (11). Ayrıca su otu, melek otu, tek boynuzlu at kökü, mavi kohoş, çin yüksük otu, ısırgan otu, papaz külahı, çuha çiçeği yağı, sarı kantron ve melek otu kadınların arasında fertilite için kullanıldığı bildirilmektedir $(5,12)$.

\section{Çin Bitkisel Tedavisi}

İnsanlık tarihiyle birlikte bitkilerin tedavide kullanımlarına başlanmıştır. Modern tıpta ise pek çok ilaç da yine bitkilerden üretilmektedir. Geleneksel bitkisel ilaç uygulamaları kültürel farklılıklara rağmen neredeyse her kültürün bir parçasını oluşturmaktadır. Batı herbalizminde sıklıkla bitkiler tek kullanılırken, Çin Tıbbı'nda ise bitkilerin karışımlar şeklinde kullanımı ağırlık kazanmaktadır (13). 
Çin bitkisel tedavi yöntemi, endometriyum dokusunu geliştirir, uterusa olan kan akımını artırır ve sempatik sinir sistemini uyarıcı etki ettiği belirtilmektedir (11). İncelenen bir sistematik derlemede çin bitkisel tedavisi kullanan infertil kadınların gebelik oranlarında artış görüldüğü belirtilmiştir (14). Ried ve Stuart'1n (2011) yaptığı meta-analiz çalışmalarında ise, çin bitkisel tedavisi alan infertil kadınların, diğer standart tedavi ve In Vitro Fertilizasyon (IVF) tedavisi uygulanan kadınlara oranla 3 kat daha çok gebe kalabildikleri belirlenmiştir. Bitkisel terapi yöntemi ile ilk dört ayda gebe kalabilme oranı \%60 iken ilaç tedavisi ile \%30'dur (15). Farklı bir çalışmada IVF ile birlikte aynı anda akupunktur ve Çin Bitkisel Terapi uygulanan kadınların kontrol grubuna göre gebe kalabilme oranları ve gebeliğin sürdürülebilirliği akapunktur ve çin bitkisel tedavisi almayan kadınların grubuna göre daha yüksek bulunmuştur (12).

\section{Vitamini}

İnfertilitenin etiyolojik faktörleri arasında yer alan D vitamini eksikliğinin, yapılan çalışmalarda endometriozis (16) ve polikistik over sendromu (17) ile ilişkili olduğu ortaya çıkartılmıştır. Merhi ve arkadaşlarının (2014) aktardığına göre ovarian yetmezlik ile D vitamini arasında pozitif ilişki bildirilmiştir. Ovarian foliküler sıvılardaki D vitamini seviyesinin antimülerian hormon salınımı ile olumlu ilişkide bulunduğu ve D vitamini seviyesinin ovarian sağlık için gerekli olan hücrelerden biri olan human granüloza hücrelerini etkileyebileceği, böylece üreme üzerinde etkin rol alabileceği bildirilmiştir (18).

Subfertil kadınlarda serum D vitamin seviyelerinin ve günlük D vitamini alımlarının fertil kadınlardan belirgin düzeyde daha düşük olduğu gösterilmiştir (19). IVF hastalarında ise foliküler sıvıda D vitamini düzeyi düşük olanlarda gebelik oranının daha düşük olduğu gösterilmiştir (20). D vitamininin IVF üzerine etkisini inceleyen bir sistematik derlemede, 13 çalışmanın yedisi $(\% 53.8)$ yeterli D vitamini seviyesinin IVF sonuçlarını pozitif anlamda etkilediğini, beşi (\%38.5) yeterli D vitamini seviyesi ile IVF sonuçları arasında ise yeterli ilişki oluşmadığı ve biri (\%7.7) yeterli D vitamini seviyesinin IVF sonuçlarını olumsuz anlamda etkilediğini bildirilmiştir. Sonuç olarak D vitamini seviyesi ile ve IVF sonuçları arasındaki ilişkiyi ortaya koyabilecek büyük ölçekli, kohort ve randomize kontrollü çalışmalara ihtiyaç olduğu görülmektedir (21).

\section{Vitamini}

Vitamin C, kollajen sentezinde antioksidan olarak görev alırken, hormon üretiminde ve salgılanmasında ayrıca görev almaktadır, hücreleri oksidatif stresten korumaktadır. Askorbik asit ise, overlerde doku ve hücre yenilenmesinde rol almaktadır. Siklıkla endometriyozis hastalarında, folikül sıvısında askorbik asit miktarının yetersiz olduğu ve bunun tedavi başarısını düşürdüğü ortaya atılmaktadır (22). A, C ve E vitaminlerinden oluşan 4 aylık bir diyet programı sonrasında ise peritoneal sıvıda ve periferal kanda endometriyozun oluşturduğu oksidatif stresin azaldı ̆̆ belirtilmektedir (6).

Luteal faz problemlerinde alınan $\mathrm{C}$ vitamini desteğinin progesteron düzeyini ve gebe kalma olasılığını artırdığı bildirilmiştir. Bunun yanında yüksek dozda alınan $C$ vitamininin olumsuz sonuçlar doğurabileceği belirtilmektedir. C vitamini desteğinin IVF tedavi alan hastalarda ise foliküler fazda kullanıldığında pozitif etkiler yaratığı belirtilmiştir (5). 


\section{Selenyum}

Selenyum, insan biyolojisi ve sağlığı için önemli bir elementtir. Artan kanıtlar, bu mineralin normal büyüme ve üremede önemli bir rol oynadığını göstermektedir (23). Yapılan bir çalışmada prematür ovaryan yetmezliği ya da açıklanamayan infertilitesi olanlarda selenyum bağlayıcı protein-1'e karşı otoantikorlar olduğu saptanmıştır (24). Yapılan bir vaka kontrollü çalışmada, IVF tedavisi gören 30 kadında, aynı yaşta hamile olmayan 13 kontrol kadına kıyasla daha düşük serum ve foliküler sıvı selenyum konsantrasyonları bulunmuştur (25). İnsanlarda üreme sağlığının daha iyi olabilmesi yeterli miktarda selenyum ile ilişkilendirilmiştir (26).

\section{Folik Asit}

Sağlıklı bir gebelik dönemi ve gebe kalmak için yeterli seviyede mineral ve vitaminlere (Demir, Folik asit) ihtiyaç duyulmaktadır. Yapılan bir çalışmada diyet ve besin tüketim düzeylerinin doğurganlığa etkisini incelendiğinde infertil kadınların fertil kadınlara oranla daha az folik asit alımı olduğu bildirilmiştir (27).

Gebe kalmadan önce folik asit kullanımının, 34 haftadan önce gerçekleşen doğumları düşürdüğü belirtilmektedir. Günlük 700 mg folik asit desteği kullanımının over kaynaklı infertilitede etkili olduğu, gebelik oluşumunu ise olumlu anlamda artırdığı belirtilmektedir (11).

\section{Hemşirelik Yaklaşımı}

İnfertilite tedavisinde TAT bakım uygulamalarının coğrafya, kültür ve geleneklere göre farkl1lık gösterebildiği bilinmektedir. Hemşireler kültürel ve coğrafi bu farklılıkları göz önünde bulundurarak danışmanlık yapmalıdır (11). Hemşirelerin, çiftleri TAT bakım uygulamaları hakkında yeterli ve doğru kullanımı hakkında bilgilendirmesi, ihtiyaç duyulan psikososyal alanda destek vermesi, etkili ve yeterli ekip içi iletişiminin sağlanarak devam ettirilmesi yönünde önemli görev ve sorumlulukları bulunmaktadır $(28,29)$. İnfertilite tedavisinde toplumlar arası kültürel farklılıklar hasta merkezli bakımın önemli bir yapısını oluşturmaktadır. İnfertil çiftlerde, kültürlere ait TAT uygulamaların bakım davranışlarının bilinmesi önemlidir. Hastaların TAT bakım uygulamaları konusuna yaklaşımını bilmek, hemşirelerin kültüre özgü ve hasta odaklı bakım uygulamasını sağlamasına destek olacaktır (30,31).

\section{SONUÇ}

İnfertilite tedavisinde biyolojik temelli uygulama kullanımının yaygınlaştığ bilinmektedir. Kadın infertilitesinde başvurulan biyolojik temelli uygulamaların tıbbi tedaviye ek olarak kullanımının faydalarına yönelik farklı sonuçlar ortaya konulduğu görülmektedir. $\mathrm{Bu}$ konunun bilimsel verilerle desteklenmesine ve daha fazla vaka-kontrol çalışmalarına ihtiyaç duyulmaktadir.

\section{Çıkar Çatışması}

$\mathrm{Bu}$ çalışmada yazarların çıkar çatışması durumları yoktur. 


\section{KAYNAKLAR}

1. World

Health

Organization

(WHO).

2020. https://www.who.int/reproductivehealth/topics/infertility/definitions/en/ (Erişim Tarihi: 08.06.2020).

2. Smith, J. F., Eisenberg. M. L., Millstein, S. G., Nachtigall, R. D., Shindel, A. W., Wing, H., et al (2010). Infertility outcomes program project group. The use of complementary and alternative fertility treatment in couples seeking fertility care: data from a prospective cohort in the United States. Fertil Steril, 93(7),2169-74.

3. Edirne, T., Arica, S. G., Gucuk, S., Yildizhan, R., Kolusari, A., Adali, E., et al. (2010). Use of complementary and alternative medicines by a sample of Turkish women for infertility enhancement: a descriptive study. BMC Complement Altern Med, 10(1), 1-7.

4. Clark, N. A., Will, M., Moravek, M. B., Fisseha, S. (2013). A systematic review of the evidence for complementary and alternative medicine in infertility. Obstet Gynecol Int J, 122(3), 202-206.

5. Avcıbay, B., Beji, N. K. (2013). İnfertilite tedavisinde tamamlayıc1/alternatif tıp uygulamalar1. Androloji Bülteni, 52, 71-74.

6. Uludağ, S. Z. (2018). İnfertilite kliniğine başvuran kadınların kullandıkları tamamlayıcı alternatif tıp uygulamalarının belirlenmesi. Geleneksel ve Tamamlayıcı Tip Dergisi, 1(1), 24-28.

7. Kocaadam, B., Akdevelioğlu, Y. (2018). Fitoöstrojenler ve üreme sağlı̆̆ı. Beslenme ve Diyet Dergisi, 46(1), 84-89.

8. Shanle, E. K., Xu, W. (2011). Endocrine disrupting chemicals targeting estrogen receptor signaling: identification and mechanisms of action. Chemical Research in Toxicology, 24(1), 6-19.

9. Paterni, I., Granchi, C., Katzenellenbogen, J. A., Minutolo, F. (2014). Estrogen receptors alpha (ERalpha) and beta (ERbeta): subtype-selective ligands and clinical potential. Steroids, 90,13-29.

10. Yanagihara, N., Zhang, H., Toyohira, Y., Takahashi, K., Ueno, S., Tsutsui, M. et al. (2014). New insights into the pharmacological potential of plant flavonoids in the catecholamine system. Journal of Pharmacological Sciences, 124(2), 123-128.

11. Özcan, H., Beji, N. K. (2016). İnfertilitede tamamlayıcı ve alternatif tıp uygulamaları. Okmeydanı Tip Dergisi, 32(1), 36-44.

12. Sela, K., Lehavi, O., Buchan, A., Kedar-Shalem, K., Yavetz, H., Lev-ari, S. (2011). Acupuncture and Chinese herbal treatment for women undergoing intrauterine insemination. Eur J Integr Med, 3(2), 77-81.

13. Beşen, Ö., Beji, N. K. (2014). Fertilite ve bitkiler. Androloji Bülteni, 59, 286-289.

14. Tan, L., Tong, Y., Sze, S. C. W., Xu, M., Shi, Y., Song, X. Y., et al. (2012). Chinese herbal medicine for infertility with anovulation: A systematic review. BMC Complement Med Ther, 18(12), 1087-1100. http://dx.doi.org/10.1089/acm.2011.0371.

15. Ried, K., Stuart, K. (2011). Efficacy of traditional chinese herbal medicine in the management of female infertility: A systematic review. BMC Complement Med Ther, 19(6), 319-331.

16. Pagliardini, L., Vigano, P., Molgora, M., Persico, P., Salonia, A., Vailati, S. H., et al. (2015). High prevalence of vitamin D deficiency in infertile women referring for assisted reproduction. Nutrients, 7(12), 9972-9984.

17. Dipanshu, S., Chakravorty, R. (2015). The relationship between vitamin D, insulin resistance and infertility in PCOS women. Gynecological Obstetri (Sunnyvale), 
5(294), 2161-0932.

18. Merhi, Z., Doswell, A., Krebs, K., Cipolla, M. (2014). Vitamin D alters genes involved in follicular development and steroidogenesis in human cumulus granulosa cells. Int J Clin Endocrinol Metab, 99(6), E1137-E1145.

19. Al-Jaroudi, D., Al-Banyan, N., Aljohani, N. J., Kaddour, O., Al-Tannir, M. (2016). Vitamin D deficiency among subfertile women: case-control study. Gynecological Endocrinology, 32(4), 272-275.

20. Ozkan, S., Jindal, S., Greenseid, K., Shu, J., Zeitlian, G., Hickmon, C., et al. (2010). Replete vitamin D stores predict reproductive success following in vitro fertilization. Fertil Steril, 94(4), 1314-1319.

21. Teskereci, G., İlkay, B. D. (2017). D Vitamini ve in vitro fertilizasyon sonuçları üzerine bir derleme. Sağllk Bilimleri ve Meslekleri Dergisi, 4(3), 252-259.

22. Prieto, L., Quesada, J. F., Cambero, O., Pacheco, A., Pellicer, A., Codoceo, R., et al. (2012). Analysis of follicular fluid and serum markers of oxidative stress in women with infertility related to endometriosis. Fertil Steril, 98(1), 126-130.

23. Mistry, H. D., Pipkin, F. B., Redman, C. W., Poston, L. (2012). Selenium in reproductive health. American Journal of Obstetrics and Gynecology, 206(1), 2130 .

24. Edassery, S. L., Shatavi, S. V., Kunkel, J. P., Hauer, C., Brucker, C., Penumatsa, K., et al. (2010). Autoantigens in ovarian autoimmunity associated with unexplained infertility and premature ovarian failure. Fertil Steril, 94(7), 2636-2641.

25. Özkaya, M. O., Nazıroğlu, M., Barak, C., Berkkanoglu, M. (2011). Effects of multivitamin/mineral supplementation on trace element levels in serum and follicular fluid of women undergoing in vitro fertilization (IVF). Biological trace element research, 139(1), 1-9.

26. Sattar, T. (2021). Selenium role in reproduction, pregnant/postpartum women and neonates: A current study. Current Nutrition \& Food Science, 17(1), 28-37.

27. Başar, Ö. Ü. F. (2019). İfertilitede tamamlayıcı ve alternatif tıp uygulamalart. In 4th International Scientific Research Congress (p. 97).

28. Turan, N., Öztürk, A., Kaya, N. (2010). Hemşirelikte yeni bir sorumluluk alanı: Tamamlayıcı terapi. Maltepe Üniversitesi Hemşirelik Bilim ve Sanatı Dergisi, 31, 93-8.

29. Ilgaz, A., Gözüm, S. (2016). Tamamlayıcı sağlık yaklaşımlarının güvenilir kullanımı için sağlık okuryazarlığının önemi. Dokuz Eylül Üniversitesi Hemşirelik Fakültesi Elektronik Dergisi, 9(2), 67-77.

30. Aarts, J. W. M., Faber, M. J., Van Empel, I. W. H., Scheenjes, E., Nelen, W. L. D. M., Kremer, J. A. M. (2011). Professionals' perceptions of their patients' experiences with fertility care. Human Reproduction, 26(5), 1119-1127.

31. Read, S. C., Carrier, M. E., Whitley, R., Gold, I., Tulandi, T., Zelkowitz, P. (2014). Complementary and alternative medicine use in infertility: cultural and religious influences in a multicultural Canadian setting. BMC Complement Med Ther, 20(9), 686-692. 